\title{
HUBUNGAN USIA IBU BERSALIN DENGAN KEJADIAN PREEKLAMPSIA (Di RS Aura Syifa Kabupaten Kediri Bulan Maret Tahun 2016)
}

\author{
Widya Kusumawati ${ }^{1}$, Inneke Mirawati ${ }^{2}$ \\ ${ }^{1,2}$ Akademi Kebidanan Dharma Husada Kediri Jawa Timur
}

\begin{abstract}
Abstrak
Preeklampsia merupakan penyakit dengan gejala klinis berupa hipertensi dan proteinuria yang timbul karena kehamilan akibat vasospasme dan aktivasi endotel saat usia kehamilan di atas 20 minggu. Menurut Bobak (2007), usia yang rentan mengalami preeklampsia adalah usia $<20$ tahun atau $>35$ tahun. Keadaan alat reproduksi yang belum siap menerima kehamilan mempunyai risiko lebih besar untuk mengalami kecenderungan naiknya tekanan darah, sehingga meningkatkan terjadinya preeklampsia. Sedangakan pada usia $>35$ tahun, rentan terjadinya berbagai penyakit dalam bentuk hipertensi dan eklampsia. Tujuan penelitian ini adalah untuk mengetahui hubungan antara usia ibu bersalin dengan kejadian preeklampsia di RS Aura Syifa Kabupaten Kediri Bulan Maret Tahun 2016.

Desain penelitian ini adalah korelasi dengan pendekatan retrospektive. Populasi penelitian ini sebanyak $291 \mathrm{ibu}$ bersalin, pengambilan sampel menggunakan teknik total sampling. Variabel independen penelitian ini adalah usia ibu bersalin dan variabel dependennya adalah kejadian preeklampsia. Data diperoleh dari rekam medik pada bulan Maret 2016 yang direkap dengan checklist dan diolah menggunakan editing, coding, scoring, tabulating. Kemudian dianalisis dengan uji statistic chi kuadrat dengan taraf signifikan 5\%.

Hasil penelitian menunjukkan dari $291 \mathrm{ibu}$ bersalin, yang menderita preeklampsia mayoritas berusia 20-35 tahun (4,5\%) dan minoritas berusia $<20$ tahun $(0,7 \%)$. Berdasarkan analisa data menggunakan chi kuadrat, tabel $=5,991$ sedangkan hitung $=337,47$, maka hitung $>$ tabel, maka H1 diterima. Artinya ada hubungan antara usia ibu bersalin dengan kejadian preeklampsia.

Diharapkan petugas kesehatan memberikan penyuluhan kepada ibu hamil dan bersalin dengan cara ANC teratur sesuai jadwal yang ditentukan untuk dapat mengetahui komplikasi secara dini pada ibu hamil maupun bersalin.
\end{abstract}

Kata kunci : Usia, Ibu bersalin, Preeklampsia.

Korespondensi : Jl. Ahmad Dahlan Gg II No 14 Mojoroto Kediri Jawa Timur HP : 085722223910, email : widya.koesoemawati@gmail.com 


\section{Pendahuluan}

Preeklampsia adalah penyakit dengan gejala klinis berupa hipertensi dan proteinuria yang timbul karena kehamilan akibat vasospasme dan aktivasi endotel saat usia kehamilan di atas 20 minggu. Preeklampsia terjadi pada 3,9\% dari semua wanita hamil di seluruh dunia. Angka kejadiannya di beberapa rumah sakit di Indonesia juga cenderung meningkat, yaitu $1,0 \%-1,5 \%$ pada sekitar 1970-2000 (Denantika O, et al, 2015).

Faktor penyebab preeklampsia sampai sekarang belum diketahui dengan pasti, namun terdapat beberapa teori yang dapat menjelaskan penyebab preeklampsia yaitu primigravida, kehamilan ganda, hidramnion, molahidatidosa, timbulnya hipertensi, edema, proteinuria, kejang dan koma. Sedangkan faktor presdiposisi preeklamsia yaitu molahidatidosa, diabetes mellitus, kehamilan ganda, hidrosefalus, obesitas, umur yang kurang dari 20 tahun dan lebih dari 35 tahun (Padila, 2015:148-149).

Menurut Bobak (2007), usia yang rentan mengalami preeklampsia adalah usia $<20$ tahun atau $>35$ tahun. Seperti yang telah dijelaskan Manuaba pada usia $<20$ tahun, keadaan alat reproduksi belum siap untuk menerima kehamilan karena pada umur $<20$ tahun rahim dan panggul ibu seringkali belum tumbuh mencapai ukuran dewasa. Akibatnya diragukan keselamatan dan kesehatan janin dalam kandungan. Bahaya yang dapat terjadi adalah bayi lahir belum cukup bulan, perdarahan sebelum dan sesudah melahirkan, kecenderungan naiknya tekanan darah dan pertumbuhan janin terhambat, maka hal ini meningkatkan terjadinya keracunan kehamilan dalam bentuk preeklampsia dan eklamsia. Sedangakan pada usia 35 tahun atau lebih, rentan terjadinya berbagai penyakit dalam bentuk hipertensi dan eklamsia. Hal ini disebabkan karena terjadinya perubahan pada jaringan alat-alat kandungan dan jalan lahir tidak lentur lagi (Rochjati, 2007). Selain itu, hal ini juga diakibatkan karena tekanan darah yang meningkat seiring dengan pertambahan usia. Sehingga pada usia 35 tahun atau lebih dapat cenderung meningkatkan risiko terjadinya preeklampsia (Ayurai, 2009).

Dampak preeklampsia pada ibu yaitu kelahiran prematur, oliguria, kematian, sedangkan dampak pada janin yaitu pertumbuhan janin terhambat, oligohidramnion, dapat pula meningkatkan morbiditas dan mortalitas (Yogi, ED et al, 2014). Tindakan pencegahan gejala preeklampsia/eklamsia pada wanita hamil sangat penting agar tidak terjadi hal berbahaya bagi ibu dan bayinya. Cara mengatasi preeklamsia pada ibu hamil harus dengan melakukan tindakan pencegahan sebelumnya. Bidan sebagai ujung tombak dalam memberikan pelayanan Kesehatan Ibu dan Anak (KIA) diharapkan dapat melakukan pemeriksaan antenatal yang teliti untuk dapat mengenali tanda-tanda preeklampsia sedini mungkin.

Dari uraian tersebut, maka peneliti tertarik untuk mengambil judul penelitian tentang "Hubungan usia ibu bersalin dengan kejadian preeklampsia Di RS Aura Syifa Kabupaten Kediri”.

\section{Metode}

Penelitian ini menggunakan desain penelitian korelasi dengan pendekatan retrospektif. Populasi penelitian ini sebanyak 291 ibu bersalin dan pengambilan sampel menggunakan teknik total sampling. Variabel independen penelitian ini adalah usia ibu bersalin dan variabel dependennya adalah kejadian preeklampsia. Data diperoleh dari rekam medik pada bulan Maret 2016 yang direkap dengan checklist, kemudian diolah menggunakan editing, coding, scoring, tabulating. Analisa data dengan uji statistic chi kuadrat dengan taraf signifikan 5\%. 
Hasil

Karakteristik Responden

1) Karakteristik Responden Berdasarkan Pekerjaan

\begin{tabular}{clcc}
\hline No. & Jenis Pekerjaan & Jumlah & $\begin{array}{c}\text { Prosentase } \\
(\%)\end{array}$ \\
\hline 1 & IRT & 179 & 61,5 \\
\hline 2 & Tani & 19 & 6,5 \\
\hline 3 & Swasta & 56 & 19,3 \\
\hline 4 & PNS & 19 & 6,5 \\
\hline 5 & Wiraswasta & 18 & 6,2 \\
\hline & Jumlah & $\mathbf{2 9 1}$ & $\mathbf{1 0 0}$ \\
\hline
\end{tabular}

Berdasarkan tabel, karakteristik responden yang tertinggi yaitu 179 responden $(61,5 \%)$ dengan sebanyak 18 responden $(6,2 \%)$ yang bekerja pekerjaan sebagai IRT dan yang terendah adalah sebagai wiraswasta.

\section{2) Karakteristik Responden Berdasarkan Paritas}

\begin{tabular}{clcc}
\hline No. & Paritas & Jumlah & $\begin{array}{c}\text { Prosentase } \\
\mathbf{( \% )}\end{array}$ \\
\hline 1 & Primigravida & 100 & 34,4 \\
\hline 2 & Multigravida & 191 & 65,6 \\
\hline & Jumlah & $\mathbf{2 9 1}$ & $\mathbf{1 0 0}$ \\
\hline
\end{tabular}

Berdasarkan tabel, karakteristik responden yang tertinggi adalah multigravida sebanyak 191 responden $(65,6 \%)$.

3) Karakteristik Responden Berdasarkan Pendidikan

\begin{tabular}{clcc}
\hline No. & Pendidikan & Jumlah & $\begin{array}{c}\text { Prosentase } \\
(\%)\end{array}$ \\
\hline 1 & SD & 18 & 6,2 \\
\hline 2 & SMP & 79 & 27,1 \\
\hline 3 & SMA & 169 & 58,1 \\
\hline 4 & PT & 25 & 8,6 \\
\hline & Jumlah & $\mathbf{2 9 1}$ & $\mathbf{1 0 0}$ \\
\hline
\end{tabular}

Berdasarkan tabel, prosentase tertinggi dengan $(58,1 \%)$ dan yang terendah sebanyak 18 pendidikan SMA yaitu sebanyak 169 responden responden $(6,2 \%)$ dengan pendidikan SD. 


\section{Data Khusus}

\section{1) Usia Ibu Bersalin}

\begin{tabular}{clcc}
\hline No. & \multicolumn{1}{c}{ Usia } & Jumlah & $\begin{array}{c}\text { Prosentase } \\
\mathbf{( \% )}\end{array}$ \\
\hline 1 & $<20$ tahun & 11 & 3,8 \\
\hline 2 & $20-35$ tahun & 233 & 80,1 \\
\hline 3 & $>35$ tahun & 47 & 16,1 \\
\hline & Jumlah & $\mathbf{2 9 1}$ & $\mathbf{1 0 0}$ \\
\hline
\end{tabular}

Berdasarkan tabel, karakteristik responden yang tertinggi adalah sebanyak 233 responden $(80,1 \%)$ berusia $20-35$

tahun dan terendah adalah 11 responden $(3,8 \%)$ yang berusia $<20$ tahun.

2) Preeklampsia di Aura Syifa Kabupaten Kediri bulan Maret tahun 2016

\begin{tabular}{clcc}
\hline No. & \multicolumn{1}{c}{$\begin{array}{c}\text { Klasifikasi } \\
\text { Preeklampsia }\end{array}$} & Jumlah & $\begin{array}{c}\text { Prosentase } \\
\text { (\%) }\end{array}$ \\
\hline 1 & Preeklampsia & 22 & 7,6 \\
\hline 2 & Bukan preeklampsia & 269 & 92,4 \\
\hline & Jumlah & $\mathbf{2 9 1}$ & $\mathbf{1 0 0}$ \\
\hline
\end{tabular}

Berdasarkan tabel, distribusi frekuensi yang bersalin karena preeklampsia yang bukan preekalmpsia sebanyak sebanyak 22 responden $(7,6 \%)$ dan 269 responden $(92,4 \%)$.

3) Hubungan Usia Ibu Bersalin dengan Kejadian Preeklampsia

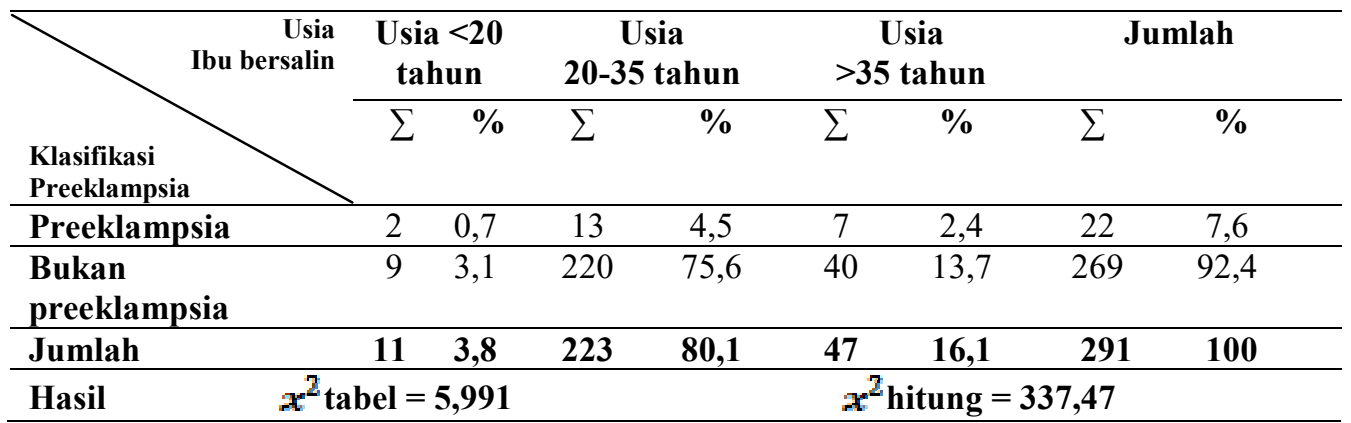

Berdasarkan tabel, dapat diketahui bahwa dari 291 responden, ibu bersalin dengan usia $<20$ tahun yang mengalami preeklampsia sebanyak 2 ibu bersalin $(0,7 \%)$ dan yang tidak mengalami preeklampsia sebanyak 9 ibu bersalin (3,1\%), usia 20-35 tahun yang mengalami preeklampsia sebanyak 13 ibu bersalin (4,5\%) dan yang tidak mengalami preeklampsia sebanyak 220 ibu bersalin $(75,6 \%)$, usia >35 tahun yang mengalami preeklampsia sebanyak 7 ibu bersalin $(2,4 \%)$ dan yang tidak mengalami preeklampsia sebanyak 40 ibu bersalin $(13,7 \%)$. Hasil analisis diperoleh jumlah $x^{2}$ tabel 5,991 dan $x^{2}$ hitung 337,47. Artinya ada hubungan antara usia ibu bersalin dengan kejadian preeklampsia 


\section{Diskusi}

\section{1) Usia Ibu Bersalin}

Berdasarkan tabel, dapat diketahui bahwa dari 291 ibu bersalin, ibu bersalin berusia $<20$ tahun yaitu 2 ibu bersalin $(0,7 \%)$, ibu bersalin yang berusia 20-35 tahun yaitu $13 \mathrm{ibu}$ bersalin $(4,5 \%)$, dan ibu bersalin yang berusia $>35$ tahun sebanyak 7 ibu bersalin $(2,4 \%)$.

Usia adalah lama waktu individu terhitung mulai saat dilahirkan sampai saat berulang tahun. Semakin cukup umur, tingkat kematangan dan kekuatan seseorang akan lebih matang dalam berpikir dan bekerja (Padila, 2014 : 104).

Usia mempunyai pengaruh terhadap kehamilan dan persalinan ibu. Usia yang kemungkinan tidak risiko tinggi pada saat kehamilan dan persalinan yaitu umur 20-35 tahun, karena pada usia tersebut rahim sudah siap menerima kehamilan, mental sudah matang dan sudah mampu merawat bayi dan dirinya. Sedangkan umur kurang dari 20 tahun dan lebih dari 35 tahun merupakan umr yang risiko tinggi terhadap kehamilan persalinan. Dengan demikian diketahui bahwa umur ibu pada saat melahirkan turut berpengaruh pada morbiditas dan mortalitas ibu maupun anak yang dilahirkan.

Dari data yang ada, mayoritas berusia $<20$ tahun sebanyak $11 \mathrm{ibu}$ bersalin $(3,8)$, usia $20-35$ tahun 233 ibu bersalin $(80,1)$ dan $>35$ tahun sebanyak $47 \mathrm{ibu}$ bersalin (16,1\%). Hal ini dihubungkan dengan status paritas ibu yang mayoritas merupakan multigravida dikarenakan usia 20-35 tahun banyak yang hamil sedangkan usia $>35$ tahun jarang hamil Sehingga semakin tua usia ibu hamil akan semakin sering melahirkan dan potensi mengalami preklampsia semakin tinggi. Hal ini disebabkan juga karena terjadinya perubahan pada jaringan alat-alat kandungan dan jalan lahir tidak lentur lagi. Sebagian responden yang berusia 20-35 tahun mengalami preeklampsia sebanyak 13 orang $(4,5 \%)$,

Menurut penelitian, usia ibu hamil yang lebih $>35$ tahun merupakan faktor predisposisi yang memiliki hubungan erat dengan kejadian preeklampsia. Sesuai dengan konsep kebidanan dikatakan bahwa usia $>35$ tahun termasuk kelompok kurang aman untuk melangsungkan kehamilan, namun demikian ada responden yang berumur $<20$ tahun dan $>35$ tahun, kondisi ini memberikan gambaran masih banyak pula responden yang berisiko dalam kehamilan sehingga memungkinkan untuk mengalami preeklampsia. Tenaga kesehatan dapat memberikan konseling tentang diet makanan, cukup istirahat, pengawasan antenatal dengan cara memeriksakan kehamilannya secara teratur. Hal tersebut berguna untuk meningkatkan pengetahuan ibu hamil tentang pentingnya pemeriksaan kehamilan berisiko dapat ditangani dengan tepat dan tidak terjadi keterlambatan penanganan serta untuk menurunkan angka kematian maternal dan perinatal.

\section{2) Preeklampsia di Aura Syifa Kabupaten Kediri bulan Maret tahun 2016}

Berdasarkan tabel dapat diketahui kejadian preeklampsia yaitu dari $291 \mathrm{ibu}$ bersalin, yang tidak mengalami preeklampsia 269 ibu bersalin $(92,4 \%)$, sedangkan yang mengalami preeklampsia sebanyak 22 ibu bersalin $(97,2 \%)$.

Preeklampsia adalah sekumpulan gejala yang secara spesifik hanya muncul selama kehamilan dengan usia lebih dari 20 minggu (Varney,2007:645). Preeklampsia adalah penyakit dengan tanda-tanda hipertensi, oedema, dan proteinuria yang timbul karena kehamilan. Penyakit ini biasanya timbul pada triwulan ke-3 kehamilan tetapi dapat timbul sebelumnya, misalnya pada mola hidatosa (Marmi, et al, 2015 :66).

Dari data yang yang diperoleh ibu bersalin yang menderita preeklampsia sebanyak $22 \mathrm{ibu}$ bersalin (7,6\%). Sesuai dengan hasil data didapatkan mayoritas ibu bersalin mempunyai status paritas multigravida 191 ibu bersalin $(65,6 \%)$ dan minoritas ibu bersalin primigravida 100 ibu bersalin $(34,4 \%)$.

Pada umumnya preeklampsia merupakan salah satu penyakit yang berbahaya dan harus diwaspadai, terutama pada ibu hamil dan ibu bersalin yang dapat menyebabkan kematian pada ibu maupun janin bila tidak ditangani dengan segera. Dapat disimpulkan bahwa preeclampsia sering terjadi pada usia tua atau $>35$ tahun karena pada usia tersebut selain terjadi kelemahan fisik dan terjadi perubahan pada jaringan dan alat kandungan serta jalan lahir tidak lentur lagi. Pada usia tersebut cenderung didapatkan penyakit lain dalam tubuh ibu salah satunya hipertensi, hal ini dikarenakan tekanan darsh tinggi yang meningkat seiring dengan penambahan usia. Tetapi preeclampsia juga bisa terjadi pada usia reproduksi sehat antara 20-35 tahun, kesenjangan ini mungkin terjadi karena preeclampsia 
dipengaruhi oleh banyak factor diantaranya factor genetic, paritas, kehamilan ganda, dan lain-lain.

Agar tidak terjadi hal tersebut disarankan ibu hamil memperhatikan kondisinya kesehatanya dengan cara konsultasi ke dokter atau bidan atau bias ke tenaga kesehatan lainnya secara teratur. Selain sebagai tenaga kesehatan dapat memberikan penyuluhan pada ibu hamil tentang deteksi dini komplikasi pada ibu hamil, konseling tentang diet makanan, cukup istirahat, melakukan kelas ibu dan disarankan pada ibu hamil untuk megikuti kelas ibu, pengawasan antenatal dengan cara memeriksakan kehamilannya secara teratur, dan sebagai tenaga kesehatan (Bidan) jika mengetahui terjadi komplikasi pada ibu hamil segera melakukan rujukan ke fasilitas kesehatan yang lebih memadai dan lengkap.

\section{3) Hubungan Usia Ibu Bersalin dengan Kejadian Preeklampsia Di Ruang Bersalin RS Aura Syifa Kabupaten Kediri}

Berdasarkan tabel, dapat diketahui bahwa dari 291 responden, ibu bersalin dengan usia $<20$ tahun yang mengalami preeklampsia sebanyak 2 ibu bersalin $(0,7 \%)$ dan yang tidak mengalami preeklampsia sebanyak 9 ibu bersalin (3,1\%), usia 20-35 tahun yang mengalami preeklampsia sebanyak $13 \mathrm{ibu}$ bersalin $(4,5 \%)$ dan yang tidak mengalami preeklampsia sebanyak $220 \mathrm{ibu}$ bersalin $(75,6 \%)$, usia $>35$ tahun yang mengalami preeklampsia sebanyak $7 \mathrm{ibu}$ bersalin $(2,4 \%)$ dan yang tidak mengalami preeklampsia sebanyak 40 ibu bersalin (13,7\%). Hasil analisis diperoleh jumlah $x^{2}$ tabel 5,991 dan $x^{2}$ hitung 337,47 .

Dari hasil uji menggunakan chi square menghasilkan nilai $x^{2}$ hitung $=337,47$, dengan $x_{\text {tabel }}^{2}=5,991$, sehingga $x^{2}$ hitung $>x^{2}$ tabel yang berarti ada hubungan yang bermakna antara usia ibu bersalin dengan kejadian preeklampsia di RS Aura Syifa Kabupaten Kediri Bulan Maret tahun 2016.

Jika dilihat dari variabel bebas, mayoritas ibu bersalin usia $<20$ tahun sebanyak 11 ibu bersalin (3,8\%), usia 20-35 sebanyak 233 ibu bersalin $(80,1 \%)$ dan $>35$ tahun yaitu sebanyak 47 ibu bersalin $(166,1 \% \%)$, dan pada variabel terikat, mayoritas ibu bersalin preeklampsia yaitu sebanyak 22 ibu bersalin (7\%).
Menurut Manuaba, et al (2010) preeklampsia merupakan timbulnya hipertensi disertai proteinuria dan edema akibat kehamilan, setelah umur kehamilan 20 minggu bila terjadi penyakit trophoblastic. Pada usia $<20$ tahun belum siap secara fisik dan mental dalam menghadapi kehamilan dan persalinan. Dari segi fisik rahim dan panggul belum tumbuh mencapai ukuran dewasa, sedangkan dari segi mental ibu belum siap untuk menerima tugas dan tanggung jawab sebagai orang tua. Pada usia 35 tahun atau lebih, rentan terjadinya berbagai penyakit dalam bentuk hipertensi dan eklamsia. Hal ini disebabkan karena terjadinya perubahan pada jaringan alat-alat kandungan dan jalan lahir tidak lentur lagi. Selain itu, hal ini juga diakibatkan karena tekanan darah yang meningkat seiring dengan pertambahan usia. Sehinggaa pada usia 35 tahun atau lebih dapat cederung meningkatkan risiko terjadinya preeklampsia (Lubis NL, 2013 : 51).

Hubungan usia ibu bersalin dengan kejadian preeklampsia dapat dipengaruhi beberapa faktor salah satunya faktor paritas. Hal ini didukung dengan hasil penelitian, bahwa mayoritas responden dengan risti yaitu dalam keadaan multigravida. Maka semakin tua usia ibu bersalin dan semakin sering melahirkan potensi untuk mengalami preeklampsia semakin tinggi. Preeklampsia sering terjadi akibat permasalahan dalam keluarga atau lingkungan sosial yang tidak mendukungnya. Beban kerja yang terlalu berat, beban, beban ekonomi keluarga yang ditanggungnya serta berbagai permasalahan keluarga juga dapat mendukung terjadinya preeklampsia atau eklamsia pada ibu hamil. Hal ini berarti status yang dialami ibu akan memicu terjadinya preeklampsia.

Dari hasil data penelitian menunjukkan bahwa preeklampsia cenderung terjadi pada ibu bersalin dengan usia $>35$ tahun, karena terjadinya perubahan pada kandungan dan jalan lahir tidak lentur lagi. Selain itu, juga diakibatkan karena tekanan darah yang meningkat seiring dengan pertambahan usia. Sehingga dengan usia $>35$ tahun berpotensi mengalami preeklampsia.

Disarankan kepada ibu hamil untuk memperhatikan kondisi kesehatannya dengan cara konsultasi ke dokter atau bidan atau bisa ke tenaga kesehatan lainnya secara teratur. Selain itu perhatian keluarga sangatlah penting diberikan pada ibu hamil, maka disarankan juga kepada keluarga untuk ikut serta dalam Jurnal Kebidanan Dharma Husada Vol. 7, No. 1 April 2018 | 68 
mengawasi kondisi kesehatan ibu hamil, dengan adanya perhatian dari keluarga ibu hamil akan mersa lebih nyaman, sehingga dapat menjalani kehamilannya dengan senantiasa bahagia. Sebagai tenaga kesehatan dapat memberikan penyuluhan pada ibu hamil tentang deteksi dini komplikasi pada ibu hamil, melakukan kelas ibu hamil, pengawasan antenatal dengan cara memeriksakan kehamilannya secara teratur, dan

\section{Simpulan}

Hasil penelitian menunjukkan bahwa ada hubungan antara usia ibu bersalin dengan

\section{Daftar Pustaka}

Arikunto, S. 2013. Prosedur Penelitian Suatu Pendekatan Praktek. Jakarta: Rineka Cipta.

Denantika O, Serudji J, Revilla Gusti. Hubungan Status Gravida ibu Terhadap Kejadian Preeklampsia di Fakultas Kedokteran Andalas Padang Jurnal Andalas 4 (1) : 212-213.

Hidayat, AAA. 2012. Riset Keperawatan Dan Teknik Penulisan Ilmiah. Jakarta : Salemba Medika.

JNPK-KR, 2008. Asuhan Persalinan Normal. Jakarta : Tim Revisi.

Kuswanti I \& Fitria. 2014. Askeb II Persalinan. Yogyakarta : Pustaka Praja.

Lubis, NL, 2013. Psikologi Kespro Wanita Dan Perkembangan Reproduksinya. Jakarta : Kencana Perdana Media Group.

Manuaba, IGB. 2010. Ilmu Kebidanan, Penyakit Kandungan Dan KB. Jakarta : EGC.

Marmi, Suryaningsih ARM, Fatmawati E. 2015. Asuhan Kebidanan Patologi. Yogyakarta : Pustaka Pelajar.

Mochtar Rustam, 2013. Sinopsis Obstetri. Jakarta : EGC.

Nursal, Tamela, Fitrayeni Faktor Risiko Preeklampsia Pada Ibu Hamil Jurnal Kesehatan Masyarakat Andalas, 10 (1) 38:44.

Nursalam, 2013. Metodologi Penelitian Ilmu Keperawatan. Jakarta : 2013.

Norma N dan Dwi M. 2013. Asuhan Kebidanan Patologi. Yogyakarta : Nuha Medika. bagi tenaga kesehatan yang memberikan layanan kesehatan dirumah apabila mengetahui terjadi komplikasi pada ibu hamil segera melakukan rujukan ke fasilitas kesehatan yang lebih memadai dan lengkap

kejadian preeklampsia dengan analisis hasil $x^{2}$ hitung $>$ dari $x^{2}$ tabel maka H1 diterima.

Notoatmodjo, S. 2010. Metodologi Penelitian Ilmu Keperawatan. Jakarta : Rineka Putri.

2012. Metodologi Penelitian Kesehatan. Jakarta : Rineka Putri.

Padila. 2014. Keperawatan Maternitas. Yogyakarta : Nuha Medika.

— 2015. Asuhan Keperawatan Maternitas II. Yogyakarta : Nuha Medika.

Purwaningsih W, \& Fatmawati S. 2010. Asuhan Keperawatan Maternitas. Yogyakarta : Nuha Medika.

Prastiwi, CS, 2013. Faktor Risiko Ibu Hamil. Yogyakarta. Prodi DIII Kebidanan STIKES Aisyiyah.

Prawirohardjo, S. 2009. Ilmu Kebidanan. Jakarta : PT.Bina Pustaka Sarwono. . 2013. Ilmu Kebidanan. Jakarta : PT. Bina Pustaka Sarwono.

Rakorpop Kementrian RI. 2015. Kesehatan Dalam Kerangka Sustainable Development Goals (SDG's).

Retnani TRI, 2014. Umur Dan Paritas Ibu Bersalin Dengan Kejadian Preeklampsia. Surabaya. Akademi Kebidanan Griya Husada. '

Rukiah, A, et al. 2009.Asuhan Kebidanan II Persalinan.Jakarta: Trans Info Media.

Sabarguna, 2008. Karya Tulis Ilmiah Untuk Mahasiswa D3 Kesehatan. Jakarta: IKAP.

Sofian, A. 2013. Sinopsis Obstetri Jilid 1. Jakarta : EGC.

Sugiyono, 2012. Statistika Untuk Penelitian. Bandung : Alfabeta. 
Sulistyawati, A. 2009. Asuhan Kebidanan Pada Masa Kehamilan. Jakarta : Salemba Medika.

Varney, H. 2007. Buku Ajar Asuhan Kebidanan. Jakarta : EGC.

Yogi ED, Haryanto, Sonbay E. Hubungan Antara Usia Dengan Preeklampsia

Pada Ibu Hamil di POLI KIA RSUD Kefamenanukabupaten Timor Tengah Utara Jurnal Delima Harapan 3 (2) 10-19.

Damayanti, I, et al. 2014. Asuhan Kebidanan Komprehensif Pada Ibu Bersalin Dan Bayi Baru Lahir [e-book] Yogyakarta: CV Budi Utama Diakses dari: https://books.google.co.id/books?id=U B7vCAAAQBAJ\&pg $=$ Faktor+faktor+y ang + mempengaruhi + persalinan $=$ false $[0$ $7 \mathrm{Mei} 2016$

Den ger. 2012. Pengertian Patologi Kehamilan. Mei 2012. http//worldhealthbokepzz.blogspot.c om/2012/05/pengertian-patologikehamilan.htm (Diakses 23 Mei 2016). 